\title{
Prevalence of diseases, morbidity and mortality of Black Bengal Goats under different management systems in Bangladesh
}

\author{
M A Kashem ${ }^{1}$; M A Hossain ${ }^{2}$, S S U Ahmed ${ }^{3}$, M A Halim ${ }^{4}$ \\ ${ }^{1}$ Department of Microbiology, ${ }^{2}$ Department of Pathology and Parasitology, ${ }^{3}$ Department of Medicine and Surgery, \\ ${ }^{4}$ Department of Agricultural Economics and Social Science, Chittagong Veterinary and Animal Sciences University, \\ Khulshi-4202, Chittagong
}

\begin{abstract}
A study was carried out in Faridpur, Habiganj and Barisal to identify the prevalence of diseases, morbidity and mortality of Black Bengal goats (BBGs) under semi-intensive system reared by moderate and ultra poor households in Bangladesh during the period from February 2008 to July 2009. A total of 168 female goats and 9 bucks were recorded from two types of households of which 125 goats were infected $(74.70 \%)$ by a number of diseases and lead to mortality (17.26\%). Survival rates and mortality percentage of kids were 80.60 and 19.40, respectively but the highest mortality was in Habiganj (21.18\%). Seasons had special influences on mortality of adult goats (35.81\%) and kids (64.19\%) where the highest mortality rates were $22.22 \%$ and $25.93 \%$, respectively in rainy season. PPR had the highest mortality rates (37.93\% in adults and $25.00 \%$ in kids) followed by pneumonia $(24.14 \%$ and $21.15 \%$, respectively). Predator invasion was the other remarkable cause for increased kids' mortality $(23.08 \%)$. The study suggests that hygienic management practices, adequate supply of nutrients, and vaccination and deworming programmes in semiintensive rearing system of BBGs at rural level will improve the survival rates of adult goats and kids.
\end{abstract}

Key words: Prevalence, survival rates, morbidity, mortality, seasons, Black Bengal goats.

\section{Introduction}

Black Bengal goat (BBG) is one of the most important livestock species in Bangladesh, which is known as "poor man's" cow. It is very important in rural economy and could be used as a tool for poverty reduction in Bangladesh. Generally goats are raised by poor farmers and distressed women with very little capital investment. Livestock is an important segment of mixed farming system in Bangladesh, which contributes about $2.90 \%$ in GDP (FAO, 1991). Goats, as far as known, were probably the first domesticated animals and most of the goats (90\%) reared are BBGs for their good traits (Devendra and Burns, 1983; Hussain, 1999; Amin et al., 2001). Nutritional deficiency of kids, especially due to pre and postnatal maternal nutritional deficiency, cause relatively low birth weight, slow growth rate and insufficient milk production by does were identified as the major constraints directly associated with higher kid mortality (Husain, 1993). Season and type of births, birth weight and parity have significant effect on kid mortality (Acharya, 1988). Viral diseases like PPR, goat pox, contagious ecthyma and viral pneumonia, and bacterial diseases such as enterotoxaemia, tetanus, brucellosis, mastitis and metritis, mycotic diseases like ring worm infection, and rickettial infections like conjunctivitis are common causes for goat mortality in rural areas. Gastro-intestinal nematodiasis, fascioliasis and tape worm causes less mortality but cause severe depression in the growth and reproductive rate of the BBGs. Lack of proper care and overall faulty husbandry practices are also responsible for higher goat mortality in the prevailing production system (Husain et al., 1995). The survival rate and average growth potential are two factors for increasing meat production. In the rural areas high mortality rate of kids are regarded as the most important constraint in goat production. Among various factors affecting kid mortality during the pre-weaning period, birth weight was the most important. Mortality rate decreases with the increase of birth weight (Husain, 1993). High level of kid mortality represents a significant barrier to increase productivity in goat rearing and also reduce the efficiency of production in all types of goat production enterprises (Sherman, 1987). Considering the above situations, the present study was undertaken to investigate the disease prevalence, morbidity and mortality of BBGs in relation to season, location and management systems and possible causes of mortality of adult goats and kids in the selected areas.

\section{Materials and Methods}

The present study was conducted in three districts viz. Faridpur, Habiganj and Barisal, from February 2008 to July 2009. A two-stage stratified sampling procedure was applied for the selection of farmers to conduct this field based experiment. In the first stage, three districts were selected purposively from Microfinance and Technical Support Project areas under Palli Karma Sahayak Foundation. Subsequently two villages were selected from an Upazila under each district and selected two types of goat rearers such as moderate and ultra poor households. The necessary preliminary data related to the objectives of the study were collected from the NGO workers and finally by interviewing the selected farmers. A distinction was made between the ultra poor and moderate poor households by considering some criteria. Beneficiaries occupying only homestead areas, having no crop lands and calorie intake less than $1800 \mathrm{kcal} /$ day were termed ultra poor households; while those occupying homestead areas, having land areas up to 0.50 acres and calorie intake less than $2122 \mathrm{kcal} /$ day were termed moderate poor 
households. A total of 12 households from each category were chosen from selected NGO beneficiaries. As a whole, a total of 72 households came under the study for rearing BBGs. Three separate ultra poor households were also selected from two adjacent villages for rearing of buck (as buck rearers) for breeding of the does of the study areas as well as for serving neighbouring areas at a reasonable rate. A total of 168 six month-old does and 9 breeding bucks were distributed among two types of beneficiaries at three locations. Both the moderate and ultra poor households were divided into three herd sizes such as herd size 1,2 and 3 with 1,2 and 4 numbers of goats respectively. Breeding bucks were given to three separate beneficiaries in each selected district. Data were collected from standard record keeping books by locally employed field assistants. The following data were recorded: number of goats distributed, number of kids born, infected goats and kids, dead goats and kids, seasonal influence (summer, winter and rainy), diagnosed diseases (based on history and cardinal signs), treatment (provided by project fund) and management system (semi-intensive) of goats. The collected data were cross verified through visiting the areas and comparing the data by the field assistants. Data were then edited and coded in the project implementation office at Chittagong Veterinary and Animal Sciences University and were analyzed. Data processing included field and office editing, coding and tabulation. The data entry template was designed in Microsoft Excel. Consistency cross checks and keystroke errors were also detected and corrected accordingly.

\section{Results and Discussion}

Diseases incidence and mortality rate of adult goats according to herd sizes: Adult female goats were distributed among moderate and ultra poor households in the study area where 24,48 and 96 does were given in herd size-1, 2 and 3, respectively (Table 1). Overall morbidity and mortality of adult goats were $74.40 \%$ and $17.26 \%$ respectively. The morbidity of adult goats distributed for herd size 1, 2 and 3 were $66.67 \%$, $85.42 \%$, and $70.83 \%$, respectively. Morbidity rates of adult goats in two households respectively were $33.93 \%$ and $40.47 \%$, and mortality rates were $6.55 \%$ and $10.71 \%$ respectively. The results imply that disease incidence and mortality rates in moderate poor was somewhat lower than that of ultra poor households because of better management and feeding practices in the former. The mortality rate of adult goats were $16.67 \%$, $10.42 \%$ and $20.83 \%$ for herd size 1,2 and 3 respectively which were higher than the observed findings by Rahman et al. (1976) where 5.33\% adult goats showed mortality under farm and rural conditions.

Overall survivability and mortality rates of kids at selected study areas: Overall statistics of kids presented in Table 2 showing that survivability and mortality rates were $80.60 \%$ and $19.40 \%$, respectively. The survival rates of kids in three selected districts were found to be $80.43 \%$, $82.42 \%$ and $78.82 \%$ whereas mortality rate of kids were $19.56 \%, 17.58 \%$ and $21.18 \%$ at Faridpur, Barishal and Habiganj respectively. The survival rates of kids in this study corroborate the reported value by Singh et al. (1990) and mortality rates observed comparatively lower than the reported value of Husain et al. (1995) at farm level. About $30 \%$ of kids' mortality was observed by Chowdhury et al. (2002) under semi-intensive conditions, which was almost higher than the observed findings of present study. In this study, it was also found that the ratios of survived male to female kids were 26:48, 22:53 and 25:42 at three different districts, respectively.

Table 1 Overall feature of different diseases, morbidity and mortality rates of distributed adult goats.

\begin{tabular}{|c|c|c|c|c|c|c|c|c|c|}
\hline \multirow[t]{2}{*}{ Herd Size } & \multicolumn{3}{|c|}{ No. of distributed goats } & \multicolumn{2}{|c|}{ No. of goats infected } & \multicolumn{2}{|c|}{ No. of goats died } & \multirow[t]{2}{*}{ Morbidity (\%) } & \multirow[t]{2}{*}{ Mortality (\%) } \\
\hline & MP & UP & Total & MP & UP & MP & UP & & \\
\hline Herd Size-1 & 12 & 12 & 24 & 7 & 9 & 2 & 2 & $16(66.67)$ & $4(16.67)$ \\
\hline Herd Size-2 & 24 & 24 & 48 & 19 & 22 & 1 & 4 & $41(85.42)$ & $5(10.42)$ \\
\hline Herd Size-3 & 48 & 48 & 96 & 31 & 37 & 8 & 12 & $68(70.83)$ & $20(20.83)$ \\
\hline Total & 84 & 84 & 168 & $57(33.93)$ & $68(40.47)$ & $11(6.55)$ & $18(10.71)$ & $125(74.40)$ & $29(17.26)$ \\
\hline
\end{tabular}

Figures in parentheses indicate percentages, MP= Moderate poor, UP= Ultra poor, Source: Field Survey, 2009.

Table 2.Overall statistics of kids investigated in different study areas for survivability and mortality rates.

\begin{tabular}{|c|c|c|c|c|c|c|c|}
\hline \multirow{2}{*}{ Location } & \multicolumn{3}{|c|}{ No. of kids born } & \multicolumn{3}{|c|}{ No. of kids survived } & \multirow{2}{*}{ Mortality (\%) } \\
\hline & Male & Female & Total & Male & Female & Total & \\
\hline Faridpur & 40 & 52 & 92 & 26 & 48 & $74(80.43)$ & $18(19.56)$ \\
\hline Barisal & 42 & 49 & 91 & 22 & 53 & 75 (82.42) & $16(17.58)$ \\
\hline Habiganj & 44 & 41 & 85 & 25 & 42 & 67 (78.82) & $18(21.18)$ \\
\hline Total & 126 & 142 & 268 & 73 & 143 & $216(80.60)$ & 52 (19.40) \\
\hline
\end{tabular}

Figures in parentheses indicate percentages, Source: Field Survey, 2009. 
Seasonal variation in mortality of adult goats and kids: Seasonal influence was also observed in mortality of adult goats and kids. In this study overall effects of three seasons (summer, winter \& rainy) of mortality of goats is shown in Table 3. The mortality rates of adults were found $7.41 \%$, $6.17 \%$ and $22.22 \%$ whereas in kids $13.58 \%$, $24.69 \%$ and $25.93 \%$ during summer, winter and rainy season, respectively. These observations support the reported value of Rahman et al. (1976). The average mortality rates of adults and kids among three herds considering the seasons were observed $35.81 \%$ and $64.19 \%$ respectively. Observed findings comparatively lower than the mortality rates reported by Husain et al. (1995). The highest mortality of both adults (22.22\%) and kids $(25.93 \%)$ were found in rainy season during the project implementation period.

Causes responsible for mortality of adult goats and kids in different areas: The causes of death of adult goats and kids are shown in Table 4. During study the highest percentage of adult mortality (37.93\%) was due to PPR followed by pneumonia (24.14\%) among the infectious diseases in all herd sizes. The observed findings of present study corroborate the research results reported by Hoque (1996).

Table 3 Mortality rates of adult goats and kids according to season

\begin{tabular}{|c|c|c|c|c|c|c|c|c|}
\hline \multirow{3}{*}{ Herd Size } & \multicolumn{8}{|c|}{ Mortality of adult goats and kids according to seasons } \\
\hline & \multicolumn{2}{|c|}{ Summer } & \multicolumn{2}{|c|}{ Winter } & \multicolumn{2}{|c|}{ Rainy } & \multicolumn{2}{|c|}{ All } \\
\hline & Adult & Kids & Adult & Kids & Adult & Kids & Adult & Kids \\
\hline Herd Size-1 & 1 & 2 & 1 & 4 & 2 & 1 & 4 & 7 \\
\hline Herd Size 2 & 2 & 4 & 1 & 6 & 2 & 7 & 5 & 17 \\
\hline Herd Size 3 & 3 & 5 & 3 & 10 & 14 & 13 & 20 & 28 \\
\hline Total & $6(7.41)$ & $1(13.58$ & $5(6.17)$ & $0(24.69$ & $8(22.22$ & $1(25.93)$ & $29(35.81)$ & $2(64.1$ \\
\hline
\end{tabular}

Figures in parentheses indicate percentages, Source: Field Survey, 2009.

Table 4 Causes of death of adult goats and kids in selected areas considering herd sizes

\begin{tabular}{|c|c|c|c|c|c|c|c|c|c|}
\hline \multirow{3}{*}{$\begin{array}{c}\text { Type of } \\
\text { Diseases }\end{array}$} & \multirow[t]{3}{*}{ Causes of death } & \multicolumn{8}{|c|}{ Number of goats and kids died } \\
\hline & & \multicolumn{2}{|c|}{ Herd size 1} & \multicolumn{2}{|c|}{ Herd size 2} & \multicolumn{2}{|c|}{ Herd size 3} & \multicolumn{2}{|c|}{ Total } \\
\hline & & Adult & Kids & Adult & Kids & Adult & Kids & Adult & Kids \\
\hline \multirow{5}{*}{ Infectious } & Pneumonia & 1 & 3 & 1 & 3 & 5 & 5 & $7(24.14)$ & $11(21.15)$ \\
\hline & PPR & 1 & 2 & 2 & 5 & 8 & 6 & $11(37.93)$ & $13(25.00)$ \\
\hline & $\begin{array}{l}\text { Contagious } \\
\text { ecthyma }\end{array}$ & 1 & 3 & 1 & 1 & 2 & 4 & $4(13.79)$ & $8(15.38)$ \\
\hline & Diarrhea & 1 & 2 & 1 & 4 & 2 & 3 & $4(13.79)$ & $9(17.31)$ \\
\hline & Tetanus & 0 & 0 & 0 & 0 & 0 & 1 & 0 & $2(3.85)$ \\
\hline \multirow{3}{*}{$\begin{array}{l}\text { Non- } \\
\text { infectious }\end{array}$} & Poisoning & 0 & 0 & 0 & 0 & 1 & 1 & $1(3.45)$ & 1 (1.92) \\
\hline & Predator & 0 & 3 & 0 & 2 & 0 & 7 & 0 & $12(23.08)$ \\
\hline & Accidental & 0 & 1 & 0 & 1 & 2 & 2 & $2(6.90)$ & $4(7.69)$ \\
\hline Total & & 4 & 7 & & 16 & 20 & 29 & $29(100.00)$ & $52(100.00)$ \\
\hline
\end{tabular}

Figure in the parenthesis indicate percentage, Source: Field Survey, 2009.

Other infectious diseases such as diarrhea (13.79\%) and contagious ecthyma (13.79\%) were also observed in adult goats. Non-infectious cause has lower effects on adult goats. Major causes of kids mortality $(25.00 \%)$ was also due to PPR followed by invasion of predator (23.08\%), and pneumonia (21.15\%). Kids' mortality rate dramatically increased due to infectious diseases and predator invasion. Other infectious diseases such as diarrhea (17.31\%), contagious ecthyma $(15.38 \%)$ and tetanus (3.85\%) have positive impact on kids' mortality. Similar results were observed by Chowdhury et al. (2002) where they found that $42.39 \%$ of kids died due to pneumonia followed by diarrhea (32.61\%). Sriram et al. (1982) and Koul et al. (1988) also observed that main causes of mortality were pneumonia and enteritis.

From the above findings, it is important to adopt better management and preventive intervention to reduce the adult and kids mortality in semiintensive rearing systems as well as improvement of living status of goat rearers. 


\section{Acknowledgements}

The author would like to express his deep sense of gratitude and grateful thanks to Palli Karma Sahayak Foundation (PKSF) for financial help and also to the field assistant and beneficiaries for their continued help and providing valuable information for this study.

\section{References}

Acharya, R.M. 1988. Goat Breeding and Meat Production in India. Proceeding of the workshop held in Tando Jam, Pakistan.

Amin, M.R., Hussain, S.S. \& Islam, A.B.M.M. 2001. Reproductive peculiarities and litter weight in different genetic groups of Black Bengal does. Asian-Australasian J. Anim. Sci. 14(3): 197-301.

Chowdhury, S.A., Bhuiyan, M.S.A. \& Faruk, S. 2002. Rearing Black Bengal Goat under Semi-intensive management 1. Physiological and Reproductive Performances. AsianAustralasian J. Anim. Sci. 15(4): 477-484.

Devendra, C. \& Burns, M. 1983. Goat Production in the Tropics. Commonwealth Agricultural Bureau. Slough, U.K.

FAO (Food and Agricultural Organization of the United Nations), 1991. Asian Livestock Monthly Technical Magazine of the FAO Animal Production and Health Commission for Asia and the Pacific (APHCA) 8: 85-87.
Hoque, M.S. 1996. Clinical prevalence and findings of diseases and disorders in cattle and goats at the Central Veterinary Hospital, Dhaka. MS Thesis. Department of Medicine, Bangladesh Agricultural University, Mymensingh.

Husain, S.S. 1993. A study on the Productive Performance and Genetic Potential of Black Bengal Goats, Ph.D, Thesis, Bangladesh Agricultural University, Mymensingh.

Husain, S.S., Islam, A.B.M.M. \& Horset, P. 1995. Effect of different factors on pre-weaning survivality of Black Bengal kids. Small Rum. Res. 18: 1-5.

Hussain, S.S. 1999. Sustainable genetic improvement of economic trait of Black Bengal goats through selective and cross breeding. BAU Res. Prog. 10: 72-80.

Koul, G.L., Somvansha, S. \& Biswas, J.C. 1988. Mortality pattern in Pashmina goats. Indian Vet. J. 65: 847849.

Rahman, A., Ahmed, M.U. \& Mia, A.S. 1976. Studies on the diseases of goats in Bangladesh: Mortality of goats under farm and rural conditions. Trop. Anim. Health Prod. 8: 90.

Sherman, D. M. 1987. Causes of kid morbidity and mortality. An overview. Proc. IV International Conference on Goats. Brazil, pp: 335-354.

Singh, D.K., Mishra, H.R., Deb, A.R. \& Singh, L.B. 1990. Survivability of pure and crossbred kids during first month of life under village system of management. Indian $\mathrm{J}$. Anim. Sci. 60(8): 998-1001.

Sriram, P.K., Rao, P.R. \& Naidu, N.G.R. 1982. Goat mortality in Andhra Pradesh. Indian Vet. J. 59: 96-99. 